\title{
EFFECTS OF DRYING METHODS ON THE CHARACTERISTICS OF Pleurotus sajor-caju MUSHROOM
}

\author{
NGOC GIANG NGUYEN THI ${ }^{1 *}$ and MINH THUY NGUYEN ${ }^{2}$ \\ ${ }^{1}$ An Giang University, Vietnam \\ ${ }^{2}$ Can Tho University, Vietnam \\ *E-mail:ntngiang@agu.edu.vn,nmthuy@ctu.edu.vn
}

Accepted 11 September 2020, Published online 25 October 2020

\begin{abstract}
Mushrooms of the Pleurotus spp. are very sensitive and the shelf-life of mushrooms is limited, that is a few days under normal or low temperatures, which is a limitation in the distribution and marketing of fresh products. To extend their shelf life, drying methods need to be applied. Total drying time decreased with increased drying temperatures (960 and $330 \mathrm{~min}$ of drying at 40 and $70^{\circ} \mathrm{C}$, respectively). The drying curve equations is establised as $y=a$.exp(-kt) $\left(\mathrm{R}^{2} \geq 0.95\right)$. These equations can be applied to predict moisture reduction during drying of Pleurotus spp. at the temperature ranges studied. Besides, effect of drying methods (convection, sun and solar drying) was investigated. Results showed that the quality of sample treated with solar drying was higher than others. In the solar drying samples, the highest protein, carbohydrate, flavonoid, $\beta$-glucan content (in dry basis) were $16.22 \%, 24.84 \%$ and $5.82 \mathrm{mg} \mathrm{QE} / \mathrm{gm}, 0.41 \%$, respectively. The antioxidant capacity (FRAP and DPPH) was $362.58 \mathrm{mM} \mathrm{Fe}{ }^{2+} / \mathrm{gm}$ and $62.35 \%$, respectively. The lighter color was obtained for the mushroom dried using a solar dryer.
\end{abstract}

Key words: Pleurotus spp., drying curve, solar drying, antioxidant

\section{INTRODUCTION}

Pleurotus spp. is commercially important edible mushrooms commonly known as the oyster mushroom. P. sajor-caju is one of the most successfully cultivated species of these mushrooms and it is considered to be delicious (Zang et al., 2002). This is also known as grey oyster mushroom, and this name was taken for its physical shape like a seashell. P. sajor-caju was first isolated from India (Chang \& Miles, 2004; Jandaik, 1974) and this strain was identified as the best strain to cultivate in the tropics and subtropics (Eugino \& Anderson, 1968). In An Giang province (Vietnam), P. sajor-caju are grown indoors with 2 to 3 crops per year and experience of famers cultivating mushrooms is 1 to 3 years, especially more than 10 years.

In fact, $P$. sajor-caju was said to possess unique nutritional and medicinal values, aroma as well as taste (Dunkwal \& Singh, 2007). Antioxidants in mushrooms (polyphenol, flavonoid, alkaloid,

* To whom correspondence should be addressed. terpenoid) can be protective agents to help humans in reducing oxidative damage without any intervention (Halliwell \& Gutteridge, 1986). Mushrooms are quite rich in protein, with an important content of essential amino acids and poor in fat (1.1-8.3\% - dry weight basis) (Chang \& Smiles, 2004). Mushrooms have also been proved as good source of dietary fibre and $\beta$-glucan, vitamin B-complex, D and mineral content. $\beta$-glucans are associated with its ability to exhibit significant cumulative properties, possess better antioxidant activities and the ability to scavenge against free radicals (Synytsya et al., 2008). The dietary fibers present in the mushroom can protect the body from irritable bowel syndrome and colon cancer.

However, mushrooms of the Pleurotus spp. are very sensitive and start to degrade within one day of haverst (Apati, Furlan \& Laurindo, 2010). Mushrooms can only be stored for several days in cold conditions, which is a limitation for developing of fresh products. Many different drying methods are applied to dry fruits and vegetables such as convection drying, sun drying and solar drying. Therefore, this study is carried out to investigate the 
effect of drying methods on the characteristics of Pleurotus sajor-caju mushroom to select an appropriate method for best quality.

\section{MATERIALS AND METHODS}

\section{Materials}

Pleurotus sajor-caju purchased from Chau Thanh district, An Giang province, Vietnam. Fresh mushrooms were washed with water, drained and then immersed for $15 \mathrm{~min}$ in $0.5 \%$ citric acid and $0.5 \% \mathrm{CaCl}_{2}$ to improve color and structure.

\section{Experimental design}

Mushrooms were dried as a single layer at 40 , $45,50,55,60,65,70^{\circ} \mathrm{C}$ in oven dryer (ESCO, OFA110-8, Indonesia). During drying, the sample weight was recorded after 15 min (Giri \& Prasad, 2007) until the weight of samples remained constant. Besides that, mushrooms were dried using solar dryers and by traditional sun drying method until the samples attained a constant weight.

\section{Determination of color and texture}

Color of samples was measured using a Hunter Lab colorimeter (CR 400, Konica Minolta, Japan). The texture of dried samples was determined using a Texture analyzer (CT3, Brookfield, USA).

Mathematical Modeling of drying curves (Thakor et al., 1999)

The moisture ratio (MR) $\left(\mathrm{kg} \mathrm{H}_{2} 0 / \mathrm{kg}\right.$ dry matter) of Pleurotus sajor-caju was calculated using Equation 1:

$$
M R=\frac{M_{H_{2} O}}{M_{D M}}
$$

Where, $\mathrm{M}_{\mathrm{H} 2 \mathrm{O}}=$ the weight of moisture, $\mathrm{kg}$ $\mathrm{M}_{\mathrm{DM}}$ is the mass of dry matter, $\mathrm{kg}$

Determination of protein, carbohydrate, lipid, $\beta$-glucan

The protein, lipid and carbohydrate contents were analysed according to standard methods, as described by AOAC (Association of Official Analytical Chemists, 2010). $\beta$-glucan content was analysed by Phenol-Sulfuric method (John \& Sons, 2001).

\section{DPPH (2,2-diphenyl-1-picrylhydrazyl) scavenging activity}

DPPH was measured according to Molyneux (2004) and calculated using Equation 2:
Inhibition of DPPH radical (\%)

$=100 \times\left(\mathrm{A}_{\text {control }}-\mathrm{A}_{\text {sample }}\right) / \mathrm{A}_{\text {control }}$

Where, $\mathrm{A}_{\text {control }}=$ the absorbance of the control $\mathrm{A}_{\text {sample }}=$ the absorbance of the sample

\section{Determination of Ferric reducing antioxidant assay (FRAP)}

FRAP assay (mM of $\mathrm{FeSO}_{4} /$ gm dry matter) was measured by Sudha et al. (2012). This method is based on the reduction of tripyridyltriazine complex $\left(\mathrm{Fe}(\mathrm{TPTZ})^{3+}\right)$ to blue colored $\mathrm{Fe}(\mathrm{TPTZ})^{2+}$ by antioxidants in acidic medium.

\section{Determination of total phenolic content}

Total phenolic content (mg TAE/gm) was determined using Folin-Ciocalteau reagent based on method of Singleton et al. (1999). The concentration of total phenolic compounds was calculated as equivalent to standard tannic acid graph (TAE), $\mathrm{y}=0.0021 \mathrm{x}+0.0064\left(\mathrm{R}^{2}=0.99\right)$.

\section{Determination of total flavonoid content}

This assay was described by Barros et al. (2008) with some modifications. The concentration of total flavonoid was calculated as equivalent to standard quercetin graph $(\mathrm{QE}), \mathrm{y}=8.2634 \mathrm{x}+0.0182$ $\left(\mathrm{R}^{2}=0.99\right)$.

\section{RESULTS AND DISCUSSIONS}

\section{Drying curves}

The shelf life of mushrooms is from 10 to 14 days (Kalac, 2009). To reduce the postharvest loss and extend their life time, drying methods should be applied. Pleurotus sajor-caju were dried at 40 , $45,50,55,60,65$ and $70^{\circ} \mathrm{C}$ in oven with air velocity at $1.0 \mathrm{~m} / \mathrm{s}$; besides, mushrooms dried by sun $\left(40^{\circ} \mathrm{C}\right)$ and solar drying $\left(45-47^{\circ} \mathrm{C}\right)$. The moisture content versus drying time are presented in Figure 1. The drying rates of mushroom samples were affected by the temperatures and increased with increasing in temperatures. As shown in Figure 1, total drying time decreased with increased in drying temperature.

Drying time of samples were calculated as 960 , $840,750,600,480,420,330 \mathrm{mins}$ at 40, 45, 50, 55, 60,65 and $70^{\circ} \mathrm{C}$, respectively for the samples reached a final moisture content $0.101 \pm 0.008(\mathrm{~kg}$ $\mathrm{H}_{2} \mathrm{O} / \mathrm{kg}$ dry matter). As the temperature increased, the phase transition is fast, so the evaporation is faster. According to Giri et al. (2007), heating at temperature of $40^{\circ} \mathrm{C}$ and $70^{\circ} \mathrm{C}$, the ability to drain moisture at $70^{\circ} \mathrm{C}$ is higher than $40^{\circ} \mathrm{C}$. According to the study of Chong et al. (2008), the drying time is inversely proportional to the drying temperature, 


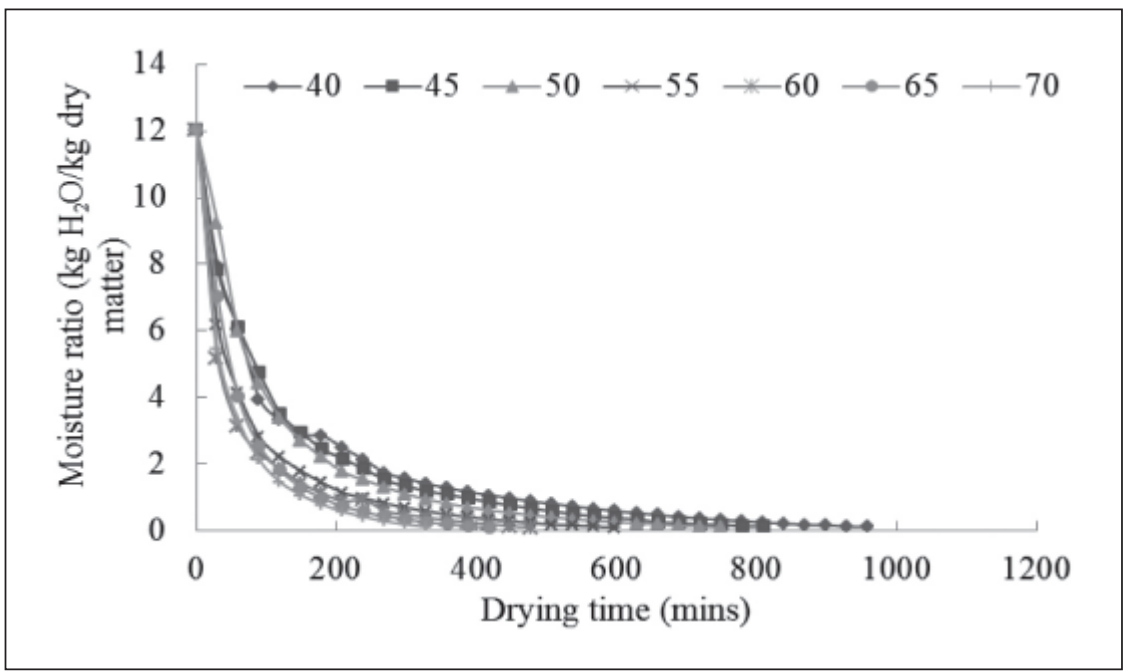

Fig. 1. Effect of drying temperature and time on moisture ratio of mushrooms.

the higher the temperature, the faster the time to drain moisture. Results are good in agreement with the earlier observations of drying the various products (Nguyen et al., 2018; Yahya, 2011). From Figure 1, the moisture content rapidly reduced at the beginning of the drying process (about 120 min) and then slowly decreased with increasing in drying time. Drying curve equations at different temperatures are presented in Table 1.

\section{Effect of drying methods on the characteristic of Pleurotus sajor-caju}

The nutritional composition and antioxidant capacity of dried mushroom samples at different drying methods are presented in Table 2. All nutritional values of samples dried by different drying methods were significantly $(p \leq 0.05)$ different from each other, except $\beta$-glucan. It is clear from the experimental and statistical data that the quality of the sample treated with solar drying was higher than others. Significantly highest protein, carbohydrate, flavonoid, $\beta$-glucan content (dry basis) (16.22\%, 24.84\% and 5.82 mg QE/gm, 0.41\%, respectively) was observed for the sample dried by solar drying. No significant difference of lipid, total phenolic content were observed in solar dried sample and in oven dried at $45^{\circ} \mathrm{C}$ (dry basis) (1.49 and $1.53 \% ; 40.04$ and $48.38 \mathrm{mg}$ TAE/gm, respectively). It can be concluded that drying at different methods but at the same temperature [solar drying $\left(45-47^{\circ} \mathrm{C}\right)$ and drying at $45^{\circ} \mathrm{C}$ ] did not affect the lipid and total phenolic content. In this study, antioxidant capacity was determined using ferric reducing antioxidant power (FRAP) and free radical scavenging activity of DPPH. The results showed that no significant difference about FRAP and DPPH was observed for the samples at different drying methods. Therefore, it can be inferred that
Table 1. Drying curve equations at different temperatures

\begin{tabular}{ccc}
\hline $\begin{array}{c}\text { Drying } \\
\text { temperature }\left({ }^{\circ} \mathrm{C}\right)\end{array}$ & Equation & $\mathrm{R}^{2}$ \\
\hline 40 & $\mathrm{y}=6.557 \mathrm{e}^{-0.004 \mathrm{x}}$ & 0.9791 \\
45 & $\mathrm{y}=7.332 \mathrm{e}^{-0.005 \mathrm{x}}$ & 0.9870 \\
50 & $\mathrm{y}=7.359 \mathrm{e}^{-0.006 \mathrm{x}}$ & 0.9830 \\
55 & $\mathrm{y}=6.251 \mathrm{e}^{-0.007 \mathrm{x}}$ & 0.9792 \\
60 & $\mathrm{y}=6.277 \mathrm{e}^{-0.009 \mathrm{x}}$ & 0.9746 \\
65 & $\mathrm{y}=7.9243^{-0.011 x}$ & 0.9855 \\
70 & $\mathrm{y}=8.215 \mathrm{e}^{-0.013 x}$ & 0.9871 \\
\hline
\end{tabular}

drying methods have no significant effect on the antioxidant activity. The highest FRAP (426.51 mM $\mathrm{Fe}^{2+} / \mathrm{gm} \mathrm{db}$ ) and DPPH (68.51\%) was determined in dried sample at $45^{\circ} \mathrm{C}$ and $40^{\circ} \mathrm{C}$, respectively. The antioxidant capacity of solar drying is lower than samples at $45^{\circ} \mathrm{C}$ and $40^{\circ} \mathrm{C}\left(362.58 \mathrm{mM} \mathrm{Fe}^{2+} / \mathrm{gm} \mathrm{db}\right.$ and $62.35 \%$, respectively). Various methods can be used to dry fruits and vegetables. Convection drying is the most commonly used method in the food industry because of the ease of controlling the process (Mundada et al., 2010). However, this method could damage both nutrition quality and texture, also requires a long period of drying that causes discoloration and has to be run under comparatively high temperatures (Figiel, 2010). Besides that, mechanical driers require fossil fuel an electrical energy. Sun dryers and solar dryers have the potential for adoption and application in An Giang province, Vietnam.

The color of samples was expressed as lightness $\left(\mathrm{L}^{*}\right)$, coordinate green-red $\left(\mathrm{a}^{*}\right)$ and coordinate yellow-blue $\left(b^{*}\right)$. In general, the $\mathrm{L}^{*}$ value of samples at 40 to $70^{\circ} \mathrm{C}$ decreased with increasing temperature and $a^{*}, b^{*}$ value of samples increased with increasing temperature. The overall color parameters 
Table 2. Nutritional composition and antioxidant activitiesof Pleurotus sajor-caju by different drying methods

\begin{tabular}{|c|c|c|c|c|c|c|c|c|}
\hline $\begin{array}{l}\text { Drying } \\
\text { methods }\end{array}$ & $\begin{array}{l}\text { Protein } \\
(\% \mathrm{db})\end{array}$ & $\begin{array}{l}\text { Carbohydrate } \\
(\% \mathrm{db})\end{array}$ & $\begin{array}{l}\text { Lipid } \\
\text { (\% db) }\end{array}$ & $\begin{array}{l}\beta \text {-glucan } \\
(\%)\end{array}$ & $\begin{array}{l}\text { Total } \\
\text { phenolic } \\
\text { (mg TAE/ } \\
\text { gm db) }\end{array}$ & $\begin{array}{l}\text { Flavonoid } \\
\text { (mg QE/ } \\
\mathrm{gm} \mathrm{db} \text { ) }\end{array}$ & $\begin{array}{l}\text { Frap } \\
\left(\mathrm{mM} \mathrm{Fe} \mathrm{Fe}^{2+/}\right. \\
\mathrm{gm})\end{array}$ & $\begin{array}{l}\text { DPPH } \\
(\%)\end{array}$ \\
\hline $40^{\circ} \mathrm{C}$ & $13.89^{a b c d}$ & $21.92^{b c}$ & $1.27^{\mathrm{ef}}$ & $0.13^{a}$ & $38.47^{\mathrm{abc}}$ & $3.22^{\mathrm{ab}}$ & $279.81^{a b}$ & $68.51^{b c d}$ \\
\hline $45^{\circ} \mathrm{C}$ & $15.76^{\mathrm{bcd}}$ & $22.59^{b c}$ & $1.53^{f}$ & $0.22^{a}$ & $48.38^{c}$ & $2.65^{\mathrm{a}}$ & $426.51^{\mathrm{bcd}}$ & $59.02^{b}$ \\
\hline $50^{\circ} \mathrm{C}$ & $10.05^{a}$ & $20.08^{a b c}$ & $1.01^{\mathrm{de}}$ & $0.20^{a}$ & $37.84^{a b c}$ & $2.52^{\mathrm{a}}$ & $336.20^{\mathrm{bc}}$ & $68.09^{\mathrm{bcd}}$ \\
\hline $55^{\circ} \mathrm{C}$ & $10.67^{a b c}$ & $18.61^{\mathrm{ab}}$ & $0.35^{\mathrm{a}}$ & $0.18^{a}$ & $36.12^{\mathrm{abc}}$ & $3.32^{\mathrm{ab}}$ & $306.09^{a b}$ & $63.77^{b c}$ \\
\hline $60^{\circ} \mathrm{C}$ & $10.55^{\mathrm{ab}}$ & $18.25^{a b}$ & $0.64^{\mathrm{abcd}}$ & $0.17^{a}$ & $31.00^{a}$ & $2.21^{a}$ & $221.12^{\mathrm{a}}$ & $74.54^{d}$ \\
\hline $65^{\circ} \mathrm{C}$ & $13.62^{\mathrm{abcd}}$ & $16.32^{\mathrm{ab}}$ & $0.78^{\mathrm{bcd}}$ & $0.16^{a}$ & $32.24^{\mathrm{a}}$ & $2.28^{a}$ & $357.20^{\mathrm{bc}}$ & $48.55^{a}$ \\
\hline $70^{\circ} \mathrm{C}$ & $9.59^{a}$ & $15.94^{\mathrm{a}}$ & $0.42^{\mathrm{ab}}$ & $0.17^{a}$ & $28.35^{a}$ & $3.51^{\mathrm{ab}}$ & $331.12^{\mathrm{abc}}$ & $73.52^{\mathrm{cd}}$ \\
\hline $\begin{array}{l}\text { Sun } \\
\text { drying } \\
\left(\sim 40^{\circ} \mathrm{C}\right)\end{array}$ & $15.92^{\mathrm{cd}}$ & $22.59 \mathrm{bc}$ & $1.02^{\mathrm{de}}$ & $0.24^{a}$ & $38.31^{a b c}$ & $4.17^{\mathrm{b}}$ & $314.54^{\mathrm{ab}}$ & $62.91^{b c}$ \\
\hline $\begin{array}{l}\text { Solar } \\
\text { drying } \\
\left(45-47^{\circ} \mathrm{C}\right)\end{array}$ & $16.22^{d}$ & $24.84^{c}$ & $1.49^{f}$ & $0.41^{a}$ & $40.04^{b c}$ & $5.82^{c}$ & $362.58^{\mathrm{bc}}$ & $62.35^{b c}$ \\
\hline
\end{tabular}

Different letters represent the significant difference in each column with $p \leq 0.05$.

Table 3. The color and texture of dried mushroom by different drying methods

\begin{tabular}{cllll}
\hline Drying method & \multicolumn{3}{c}{ Color parameters } & $\begin{array}{l}\text { Texture } \\
\text { (gm force) }\end{array}$ \\
\cline { 2 - 4 } & $\mathrm{L}^{*}$ & $\mathrm{a}^{*}$ & $\mathrm{~b}^{*}$ & \\
\hline Fresh mushroom & 80.40 & 1.39 & 3.52 & \\
$40^{\circ} \mathrm{C}$ & $69.75^{\mathrm{d}}$ & $1.76^{\mathrm{bc}}$ & $6.07^{\mathrm{b}}$ & $8611.83^{\mathrm{b}}$ \\
$45^{\circ} \mathrm{C}$ & $69.28^{\mathrm{d}}$ & $2.28^{\mathrm{cd}}$ & $7.17^{\mathrm{bc}}$ & $6261.80^{\mathrm{a}}$ \\
$50^{\circ} \mathrm{C}$ & $56.92^{\mathrm{c}}$ & $2.68^{\mathrm{cde}}$ & $8.22^{\mathrm{bc}}$ & $6600.00^{\mathrm{ab}}$ \\
$55^{\circ} \mathrm{C}$ & $53.05^{\mathrm{c}}$ & $2.98^{\mathrm{efg}}$ & $8.85^{\mathrm{c}}$ & $7412.33^{\mathrm{ab}}$ \\
$60^{\circ} \mathrm{C}$ & $36.68^{\mathrm{ab}}$ & $3.12^{\text {efgh }}$ & $13.36^{\mathrm{d}}$ & $7398.50^{\mathrm{ab}}$ \\
$65^{\circ} \mathrm{C}$ & $35.75^{\mathrm{ab}}$ & $3.89^{\mathrm{gh}}$ & $13.37^{\mathrm{d}}$ & $8286.67^{\mathrm{ab}}$ \\
$70^{\circ} \mathrm{C}$ & $32.96^{\mathrm{a}}$ & $4.02^{\mathrm{hi}}$ & $17.09^{\mathrm{d}}$ & $8155.33^{\mathrm{ab}}$ \\
Sun drying & $70.66^{\mathrm{d}}$ & $1.81^{\mathrm{ab}}$ & $3.65^{\mathrm{a}}$ & $5883.75^{\mathrm{a}}$ \\
Solar drying & $76.79^{\mathrm{e}}$ & $1.24^{\mathrm{a}}$ & $3.49^{\mathrm{a}}$ & $7007.75^{\mathrm{a}}$ \\
\hline
\end{tabular}

Different letters represent the significant difference in each column with $p \leq 0.05$.

of mushrooms samples were more influenced by drying methods. Non-enzymatic Maillard reaction that occurs between proteins or amino acids and reducing sugars during heating may be responsible for the formation of brown compounds (Nguyen \& Schwartz, 1999). It is clear that more browning occurred during drying because of non-enzymatic Maillard reaction. Kotwaliwale et al. (2007) noted that the increased darkening of mushroom samples dried at high temperatures could be attributed to the negative influence of high temperature on mushroom pigments.

The color and texture of dried mushroom samples by different drying methods are presented in Table 3. Our results also showed that the best color was obtained $\left(\mathrm{L}^{*}=76.79, \mathrm{a}^{*}=1.24, \mathrm{~b}^{*}=3.49\right)$ for samples dried by the solar drying, that were closest to those of fresh mushrooms samples
$\left(\mathrm{L}^{*}=80.40, \mathrm{a}^{*}=1.39, \mathrm{~b}^{*}=3.52\right)$ (Figure 2). The results are consistent with some research (Soto et al., 2001; Nour et al., 2011), they reported that the color of dried mushroom samples were a critical quality parameter to the acceptance of final product and products with high $L^{*}$ values being preferred by consumers.

There is no significant difference in firmness between samples at different drying methods at $40^{\circ} \mathrm{C}$, the shear force is highest (8611.83 gm force). Increasing drying temperature (from 45 to $70^{\circ} \mathrm{C}$ ) caused increased firmness of the product probably because the mushrooms dried faster thus the time for the breakdown of the cell structural components like pectin or cellulose were reduced (Suhaila \& Tok, 1994). Besides that, the shear force tend to increase when the drying time was longer (Yung-Sang et al., 2015). 


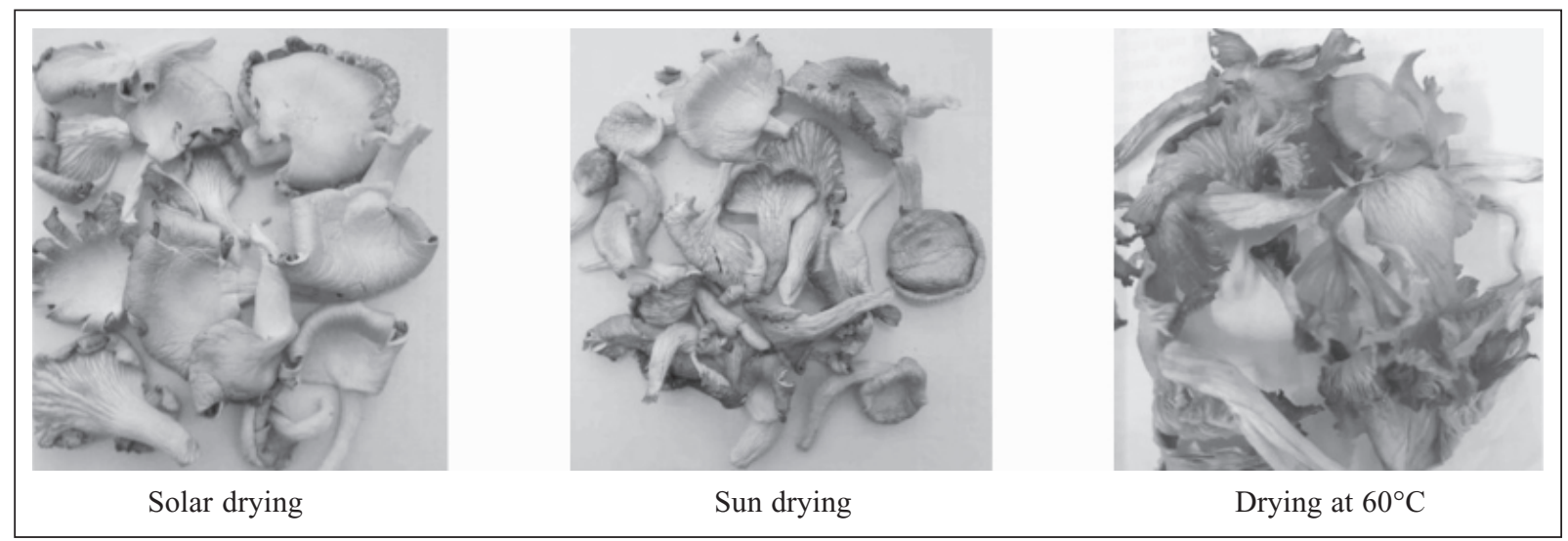

Fig. 2. Mushroom samples at different drying methods.

\section{CONCLUSION}

This research has been useful for verification of the influence of difference drying methods on the characteristic of Pleurotus sajor-caju. It was found that when changing the drying temperature from $40^{\circ} \mathrm{C}$ to $70^{\circ} \mathrm{C}$, the drying time is shortened from 960 to $330 \mathrm{~min}$. Besides, the solar drying gave the best mushroom quality. The use of this drying method can be economic, low energy consumption and environmentally friendly alternative of An Giang province (Vietnam) to help reduce the postharvest loss and increase the consumption availability of products.

\section{ACKNOWLEDGEMENT}

We gratefully acknowledge Can Tho University and An Giang University, Vietnam for supporting our research.

\section{REFERENCES}

AOAC. 2010. Official Methods of Analysis. AOAC, UK.

Apati, G.P., Furlan, S.A. \& Laurindo, J.B. 2010. Drying and rehydration of oyster mushroom. Brazil Architech Biological Technology, 53(4): 945-952.

Barros, L., Falcao, S., Baptista, O., Freire, C., VilasBoas, M. \& Ferreira, I.C.F.R. 2008. Antioxidant activity of Agaricus sp. mushrooms by chemical, biochemical and electrochemical assays. Food Chemistry, 111: 61-66.
Chang, S.T. \& Miles, P.G. 2004. Mushrooms: Cultivation, Nutritional Value, Medicinal Effect, and Environmental Effect. 2nd Ed. CRC Press, USA.

Chong, C., Law, C., Cloke, M., Hii, C., Abdullah, W. \& Daud, W. 2008. Drying kinetics and product quality of dried Chempedak. Journal of Food Engineering, 88(4): 522-527.

Dunkwal, V.J.S. \& Singh, S. 2007. Physico-chemical properties and sensory evaluation of Pleurotus sajor-caju powder as influenced by pretreatments and drying methods. British Food Journal, 109: 749-759.

Eugino, C.P \& Anderson, N.A. 1968. The genetics and cultivation of Pleurotus ostreatus. Mycologia, 60: 627-634.

Figiel, A. 2010. Drying kinetics and quality of beetroots dehydrated by combination of convective and vacuum-microwave methods. Journal of Food Engineering, 98: 461-470.

Giri, S.K. \& Prasad, S. 2007. Drying kinetics and rehydration characteristics of microwavevaccuum and convective hot - air dried mushrooms. Journal of Food Engineering, 78: 512-521.

Halliwell, B. \& Gutteridge, J.M.C. 1986. Oxygen toxicity, oxygen radicals, transition metals and disease. Biochemical, 219-224.

Jandaik, C.L. 1974. Artificial cultivation of Pleurotus sajor-caju (Fr.) Singer. Mushroom Journal, 22: 405.

John, W. \& Sons, I. 2001. Colormetric quatification of carbohydrates. Current Protocols in Food Analytical Chemistry. E1.1.1-E1.1.8.

Kalac, P. 2009. Chemical composition and nutritional value of European species of wild growing mushroom (Pleurotus spp.). Drying Technology, 6: 1995-2004. 
Kotwaliwale, N., Bakane, P. \& Verma, A. 2007. Changes in the textural and optical properties of oyster mushroom during hot air drying. Journal of Food Engineering, 78: 1207-1211.

Molyneux, P. 2004. The use of the stable free radical diphenylpicrylhydrazyl (DPPH) for estimating antioxidant activity. Songklanakarin Journal Science Technology, 26: 211-219.

Mundada, M., Hathan, B.S. \& Maske, S. 2010. Convective dehydratetion kinetics of osmotically pretreated pomegranate arils. Biosystems Engineering, 107: 307-316.

Nguyen, M.L. \& Schwartz, S.J. 1999. Lycopene: Chemical and biological properties. Food Technology, 53: 38-45.

Nguyen, T.V.L., Nguyen, Q.D., Trýõng, Q.T. \& Le, T.T. 2018. Effect of air-drying temperature on drying kinetics of four mushroom species in Vietnam. Journal of Science and TechnologyNguyen Tat Thanh University, 1: 23-27.

Nour, V., Trandafir, I. \& Ionica, M.E. 2011. Effects of pretreatments and drying temperatures on the quality of dried button mushrooms. SouthWestern Journal of Horticulture, Biology and Enviroment, 2: 15-24.

Singleton, V.L., Orthofer, R. \& Lamuela-Raventos, R.M. 1999. Analysis of total phenols and other oxidation substrates and antioxidants by means of Folin-Ciocalteu reagent. Methods Enzymol., 299: 152-178.

Soto, M.G., Camacho, R.O. \& Lopez, O.P. 2001. Effect of pretreatment and drying on the quanlity of oyster mushrooms (Pleurotus ostreatus). Drying Technology, 19: 661-672.
Sudha, G., Vadivukkarasi, S., Indhu, S.R.B. \& Lakshmanan, P. 2012. Antioxidant activity of various extracts from an edible mushroom Pleurotus eous. Food Science Biotechnology, 21: 661-668.

Suhaila, M. \& Tok, S.H. 1994. Effect of pretreatments on the characteristics of : dried grey oyster mushroom (Pleurotus sajor-caju). Pertanika Journal of Tropical Agriculture Science, 17: 111-115.

Synytsya, A., Mickova, K., Jablonsky, L., Slukova, M. \& Copikova, J. 2008. Mushrooms of genus Pleurotus as a source of dietary fibres and glucans for food supplements. Czech Journal of Food Science, 26: 441-446.

Thakor, D.L.S., Miyamoto, K., Ishibashi, K., Matsuda, K. \& Satow, T. 2001. Thin-layer drying of sweet potato chips and pressed grates. Trans. ASAE, 44(3): 669-674.

Yahya, T. 2011. Drying kinetics of Oyster mushroom (Pleurotus ostreatus) in a convection hot air dryer. Journal of Agricultural Science and Technology, 13: 655-664.

Yashwant, K., Soumitra, T.V. \& Seema, A.B. 2015. Drying: An Excellent Method for Food Preservation. International Journal of Engineering Studies and Technical Approach, 01(8): 1-17.

Yung-Sang, C., Su-Kyung, K., Jong-Dae, P., Hee-Ju, K., Aere, J. \& Young, B. 2015. Effects of drying condition and binding agent on the quality chatacteristic of ground dried - pork meat products. Korean Journal of Food Science, 35(5): 597-603. 